\title{
Avaliação da qualidade da água subterrânea na região dos Bancários em João Pessoa - PB
}

\author{
Evaluation of groundwater quality in the Bancários region in João Pessoa - PB \\ Evaluación de la calidad de las aguas subterráneas en la región de Bancários de João Pessoa - PB
}

Recebido: 08/05/2021 | Revisado: 16/05/2021 | Aceito: 19/05/2021 | Publicado: 06/06/2021

\author{
Laísa Thayse Gomes de Medeiros \\ ORCID: https://orcid.org/0000-0002-4778-0505 \\ Universidade Federal da Paraíba, Brasil \\ E-mail: 1tg.medeiros@hotmail.com \\ Cindy Deina Farto \\ ORCID: https://orcid.org/0000-0002-3092-092X \\ Universidade Federal da Paraíba, Brasil \\ E-mail: cindy.deina@academico.ufpb.br \\ Gilson Barbosa Athayde Júnior \\ ORCID: https://orcid.org/0000-0003-2815-7600 \\ Universidade Federal da Paraíba, Brasil \\ E-mail: gilson@ct.ufpb.br
}

\begin{abstract}
Resumo
As águas subterrâneas são as fontes alternativas mais procuradas para suprir a demanda do abastecimento humano, pois possuem geralmente uma boa qualidade, devido ao solo funcionar como um filtro natural para sua purificação. Nesse sentido, este trabalho teve por objetivo avaliar a qualidade das águas subterrâneas nas proximidades do bairro Bancários em João Pessoa - PB, tendo como referência a Portaria de Consolidação nº 05/2017 do Ministério da Saúde acerca dos padrões de potabilidade da água, assim como na Resolução n ${ }^{\circ}$ 396/2008 do CONAMA, que trata da classificação e diretrizes ambientais para o enquadramento das águas subterrâneas de acordo com os seus usos preponderantes. A pesquisa desenvolvida utilizou informações de 26 análises físico-químicas e bacteriológicas de água fornecidas por cinco condomínios residenciais, abrangendo o período de 2012 a 2018. Os resultados são apresentados através de gráficos para os parâmetros físico-químicos avaliados (cloreto, acidez, pH, cor, dureza total, turbidez, sólidos totais dissolvidos), enquanto a análise de variância foi realizada pelo método GT-2, com nível de significância de 5\%. A pesquisa também abordou análises bacteriológicas dos referidos poços. Os resultados evidenciaram que não existe diferença significativa do ponto de vista estatístico entre as médias dos poços, estando as amostras dentro dos padrões estabelecidos pelas legislações supracitadas, com exceção de algumas amostras para o parâmetro $\mathrm{pH}$.
\end{abstract}

Palavras-chave: Qualidade da água; Bairro bancários; Abastecimento humano.

\begin{abstract}
Groundwater is the most sought-after alternative sources to supply the demand for human supply, as they generally present a good quality, due to the soil functioning as a natural filter for its purification. In this sense, this study aimed to evaluate the quality of groundwater in the vicinity of Bancários neighborhood in João Pessoa - PB, as compared with the Portaria de Consolidação no 05/2017 from Brazilian Ministério da Saúde on water potability standards, as well as in Resolution No. 396/2008 from CONAMA that deals with the classification and environmental guidelines for the framing of groundwater according to its preponderant uses. The research used information from 26 physicochemical and bacteriological analyses of water provided by five residential condominiums, covering the period from 2012 to 2018. The results are presented through graphs for the evaluated physico-chemical parameters (chloride, acidity, $\mathrm{pH}$, color, total hardness, turbidity, total dissolved solids), while the analysis of variance was performed by the GT-2 method, with significance level of 5\%. The research also addressed bacteriological analyses of these wells. The results showed that there is no significant difference from the statistical point of view between the well means, and the samples are within the standards established by the above mentioned legislations, except for some samples for the parameter $\mathrm{pH}$.
\end{abstract}

Keywords: Water quality; Bancários neighborhood; Human supply.

\section{Resumen}

Las aguas subterráneas son las fuentes alternativas más buscadas para abastecer la demanda de suministro humano, ya que generalmente tienen una buena calidad, debido a que el suelo funciona como un filtro natural para su purificación. En este sentido, este estudio tenía como objetivo evaluar la calidad de las aguas subterráneas en las inmediaciones del barrio Bancários de João Pessoa - PB, teniendo como referencia la Portaria de Consolidação N ${ }^{\circ}$ 05/2017 del 
Ministério da Saúde de Brasil sobre las normas de potabilidad del agua, así como en la Resolucão No $396 / 2008$ de CONAMA, que se ocupa de la clasificación y directrices ambientales para el encuadre de las aguas subterráneas de acuerdo con sus usos preponderantes. La investigación utilizó información de 26 análisis fisicoquímicos y bacteriológicos de agua proporcionados por cinco condominios residenciales, cubriendo el período de 2012 a 2018. Los resultados se presentan a través de gráficos para los parámetros físico-químicos evaluados (cloruro, acidez, pH, color, dureza total, turbidez, sólidos disueltos totales), mientras que el análisis de la varianza fue realizado por el método GT-2, con un nivel de significancia del 5\%. La investigación también abordó análisis bacteriológicos de estos pozos. Los resultados mostraron que no hay ninguna diferencia significativa desde el punto de vista estadístico entre los medios del pozo, y las muestras están dentro de las normas establecidas por las legislaciones mencionadas anteriormente, excepto algunas muestras para el parámetro $\mathrm{pH}$.

Palabras clave: Calidad del agua; Distrito bancários; Suministro humano.

\section{Introdução}

O uso não racional da água e a contaminação dos corpos hídricos por fontes antrópicas vêm rapidamente comprometendo a boa qualidade e reduzindo a oferta de águas superficiais no planeta, fazendo com que se busque fontes alternativas para o abastecimento humano. As águas subterrâneas são as fontes alternativas mais procuradas para suprir a demanda do abastecimento, pois possuem geralmente uma boa qualidade, devido ao solo funcionar como um filtro natural para sua purificação. De acordo com a World Water Assessment Programme (2015), cerca de 2,5 bilhões de pessoas no mundo utilizam água subterrânea, com atendimento para consumo humano a pelo menos 50\% da população e é responsável por $43 \%$ de toda a água usada para irrigação.

No Brasil, esses recursos são amplamente utilizados. De acordo com a Agência Nacional de Águas (ANA, 2017) estima-se que a disponibilidade de água subterrânea no país seja de aproximadamente $14.650 \mathrm{~m} / \mathrm{s}$. Sua distribuição pelo território nacional não é uniforme, e a produtividade dos aquíferos é variável, havendo regiões com escassez e outras com relativa abundância. Entre os municípios brasileiros, $42 \%$ utilizam os mananciais subterrâneos como suas principais fontes de abastecimento (ANA, 2017).

Segundo a Associação Brasileira de Águas Subterrâneas (ABAS, 2018), água subterrânea é toda a água que ocorre abaixo da superfície da Terra, preenchendo os poros ou vazios intergranulares das rochas sedimentares, ou as fraturas, falhas e fissuras das rochas compactas, e que sendo submetida a duas forças (de adesão e de gravidade) desempenha um papel essencial na manutenção da umidade do solo, do fluxo dos rios, lagos e brejos.

Para o direito do uso das águas, o órgão competente concede a outorga. No estado da Paraíba, atualmente, este órgão é a Agência Executiva de Gestão das Águas (AESA), o qual possui um cadastro de 564 outorgas (maio/2017) de uso de água de poço para abastecimento público, uso comercial e industrial, vigentes e vencidas no município de João Pessoa. A concessionária de abastecimento público da cidade, a Companhia de Água e Esgoto da Paraíba (CAGEPA), conta com 30 poços cadastrados na AESA, com um volume anual outorgado de $251.846 .39 \mathrm{~m}^{3}$.

O bom funcionamento dos sistemas ambientais depende de medidas e ações para ser alcançado, para tanto, a gestão funciona como um importante instrumento para atingir este objetivo. Ressalta-se os instrumentos de gestão de águas pertinentes no Brasil: Lei Federal no 9.433 de 1997 a qual institui a Política Nacional dos Recursos Hídricos; Resolução de nº 15/2001 do Conselho Nacional dos Recursos Hídricos que trata da gestão das águas subterrâneas; Resolução do Conselho Nacional do Meio Ambiente (CONAMA) de n 396/2008 a qual dispõe sobre a classificação e diretrizes ambientais para o enquadramento das águas subterrâneas de acordo com os seus usos preponderantes; Portaria de Consolidação de $n^{\circ} 05$ do Ministério da Saúde, a qual estabelece valores máximos permitidos de parâmetros da água para consumo humano.

Com esta percepção, o objetivo deste estudo foi avaliar a qualidade das águas subterrâneas da região dos Bancários na cidade de João Pessoa - PB, utilizando dados secundários de análises físico-químicas e bacteriológicas de águas em pontos 
selecionados, bem como, verificar o enquadramento dos parâmetros avaliados com Portaria de Consolidação no 05 de 2017 do Ministério da Saúde e com a Resolução CONAMA nº 396/2008.

\section{Metodologia}

\subsection{Caracterização da Região de Estudo}

A região dos Bancários fica localizada na cidade de João Pessoa, situada no litoral do estado da Paraíba. A área é predominantemente residencial com atividade comercial bem desenvolvida. Segundo o último Censo realizado pelo Instituto Brasileiro de Geografia Estatística (IBGE), em 2010, a cidade conta com uma população de 723.515 habitantes, e, uma população estimada para 2018 de 800.323 habitantes.

O Sistema Aquífero Paraíba-Pernambuco corresponde à bacia sedimentar homônima que ocorre entre o litoral sul de Pernambuco e proximidades de Natal (RN), perfazendo uma superfície próxima dos $10.700 \mathrm{~km} 2$. O aquífero confinado da região de estudo é o Beberibe, e o aquífero livre é o Barreiras (Lima et al. 2004).

$\mathrm{O}$ aquífero Barreiras ocupa quase a totalidade do território do município de João Pessoa, possui uma espessura aproximada de 70 a 80 metros e apresenta-se aflorante em todo o litoral paraibano. Constitui-se basicamente de sedimentos areno-argilosos, mal selecionados. Esta constituição propicia o acúmulo de água em subsuperfície, nos espaços vazios entre os grãos que compõem a rocha (Meneses, 2011).

\subsection{Distribuição Espacial dos Poços}

A Figura 1 apresenta um mapa da cidade de João Pessoa e a distribuição espacial dos 05 (cinco) poços utilizados neste estudo. Cabe destacar que nenhum dos poços está compreendido no bairro dos Bancários, porém a região de estudo é tratada popularmente com esta denominação.

O Quadro 1 descreve as características de cada poço tubular avaliado, suas respectivas profundidades, o número de análises físico-químicas e bacteriológicas, o número de parâmetros por amostras e o intervalo das amostras referente aos poços individualmente. 
Research, Society and Development, v. 10, n. 6, e43510615892, 2021

(CC BY 4.0) | ISSN 2525-3409 | DOI: http://dx.doi.org/10.33448/rsd-v10i6.15892

Figura 1. Mapa da cidade de João Pessoa e distribuição espacial dos pontos em estudo.

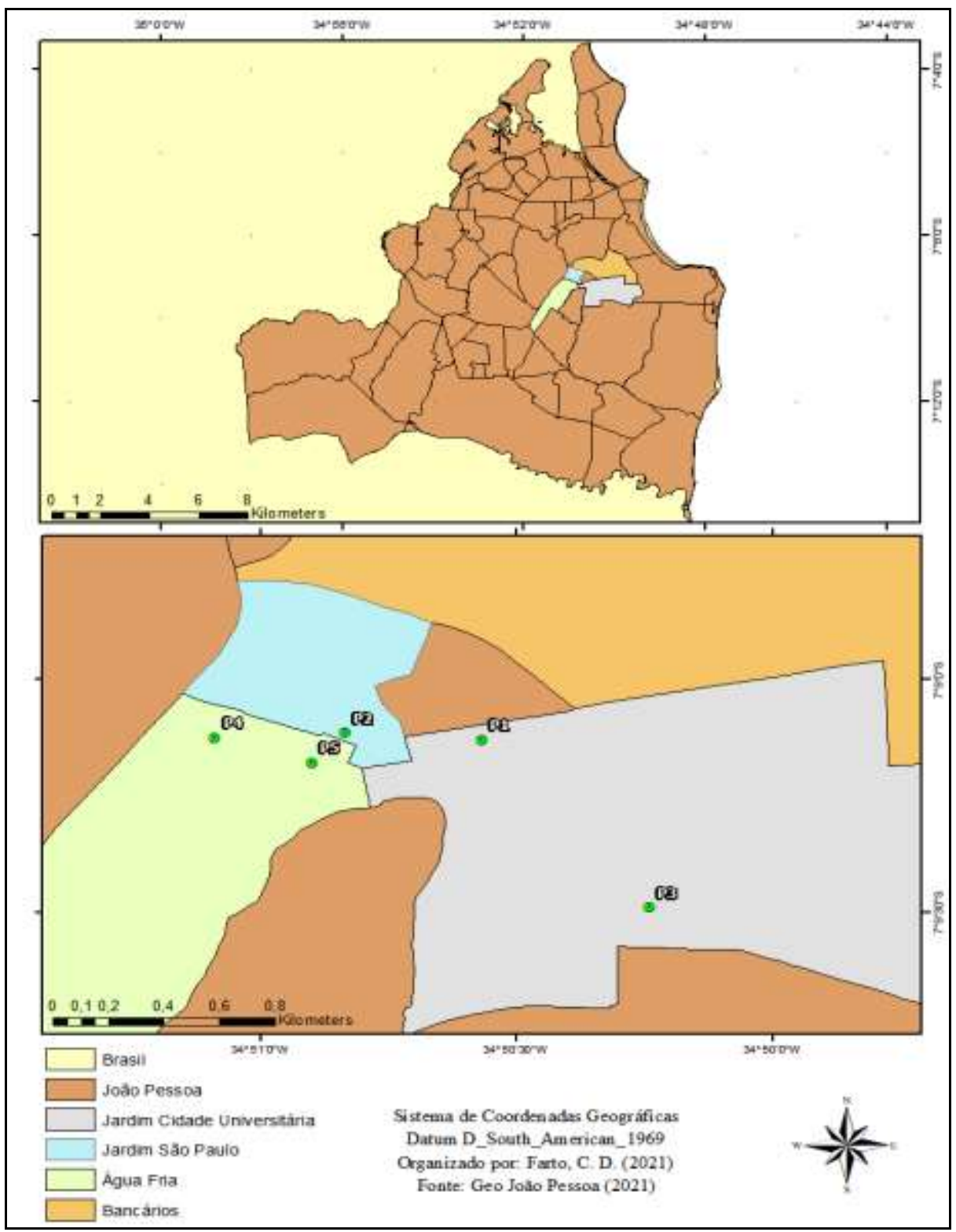

Fonte: Autores (2021).

Quadro 1. Informações acerca dos poços estudados.

\begin{tabular}{|c|c|c|c|c|}
\hline Poço & $\begin{array}{l}\text { Profundidade } \\
\text { (m) }\end{array}$ & $\begin{array}{l}\mathbf{N}^{0} \text { de Análises } \\
\text { Físico-Químicas e } \\
\text { Bacteriológica }\end{array}$ & $\begin{array}{l}\text { No }^{0} \text { de Parâmetros } \\
\text { por Amostra }\end{array}$ & $\begin{array}{l}\text { Interstício } \\
\text { temporal }\end{array}$ \\
\hline $\mathrm{P} 1$ & 40 & 5 & $7-9$ & $\begin{array}{c}25 / 07 / 2012 \mathrm{a} \\
22 / 06 / 2018\end{array}$ \\
\hline $\mathrm{P} 2$ & 40 & 12 & $8-9$ & $\begin{array}{c}29 / 05 / 2012 \mathrm{a} \\
25 / 01 / 2018\end{array}$ \\
\hline P3 & 38 & 2 & $7-9$ & $\begin{array}{c}14 / 10 / 2016 \mathrm{a} \\
08 / 05 / 2018\end{array}$ \\
\hline P4 & 35 & 2 & $7-9$ & $\begin{array}{c}14 / 11 / 2016 \mathrm{a} \\
26 / 12 / 2017\end{array}$ \\
\hline P5 & 40 & 5 & $7-9$ & $\begin{array}{c}21 / 08 / 2013 \mathrm{a} \\
21 / 06 / 2018\end{array}$ \\
\hline
\end{tabular}

Fonte: Medeiros (2018) 


\subsection{Coleta e Análise dos Dados}

Foi desenvolvida uma coleta dos dados de análises físico-químicas e bacteriológicas, in loco, com os síndicos dos condomínios que se disponibilizaram a fornecer os dados necessários para esta pesquisa. $\mathrm{O}$ fornecimento dos dados foi feito por 5 condomínios residenciais situados na região.

Os parâmetros físico-químicos e microbiológicos avaliados neste trabalho estão descritos no Quadro 2, bem como os seus respectivos Valores Máximos Permitidos na Portaria de Consolidação nº 05/2017 e na Resolução CONAMA nº 396/2008. Dos parâmetros avaliados, apenas os parâmetros cloreto, sólidos totais dissolvidos, coliformes totais e Escherichia coli, estão dispostos como relevantes para o enquadramento da água subterrânea na classe para o consumo humano.

Quadro 2. Parâmetros estudados e seus VMP na Portaria de consolidação nº 05/2017 e CONAMA nº 396/2008.

\begin{tabular}{|c|c|c|}
\hline Parâmetro & $\begin{array}{c}\text { VMP Portaria de } \\
\text { Consolidação } \\
\text { 05/17 }\end{array}$ & $\begin{array}{c}\text { VMP CONAMA } \\
\mathbf{3 9 6 / 0 8}\end{array}$ \\
\hline Cloreto & $250 \mathrm{mg} / \mathrm{L}$ & $250 \mathrm{mg} / \mathrm{L}$ \\
\hline Cor Aparente & $15 \mathrm{uH}$ & - \\
\hline Dureza Total & $500 \mathrm{mg} / \mathrm{L}$ & - \\
\hline Turbidez & $5 \mathrm{uT}$ & - \\
\hline STD & $1000 \mathrm{mg} / \mathrm{L}$ & $1000 \mathrm{mg} / \mathrm{L}$ \\
\hline $\mathrm{pH}$ & 6 à 9 & - \\
\hline Acidez & - & Ausência em $100 \mathrm{~mL}$ \\
\hline $\begin{array}{c}\text { Coliformes } \\
\text { Totais }\end{array}$ & $\begin{array}{c}\text { Ausência em } 100 \\
\mathrm{~mL}\end{array}$ & Ausência em $100 \mathrm{~mL}$ \\
\hline $\begin{array}{c}\text { Escherichia } \\
\text { Coli }\end{array}$ & $\begin{array}{c}\text { Ausência em } 100 \\
\mathrm{~mL}\end{array}$ & \multicolumn{2}{|c|}{ Fonte: Medeiros (2018). } \\
\hline \multicolumn{3}{|c|}{}
\end{tabular}

De acordo com os laudos obtidos, todas as análises físico-químicas foram realizadas seguindo as orientações contidas na publicação do Standard Methods for the Examination of Water and Wastewater (APHA, WEF \& AWWA, 2012). Para as análises bacteriológicas, o método Colilert foi utilizado, o qual permite um teste qualitativo rápido de ausência ou presença de coliformes totais e E. coli.

Ressalta-se que a desinfecção através da cloração é realizada como tratamento prévio à distribuição da água para a população atendida por cada poço. Todavia, $26,9 \%$ das análises foram realizadas com as amostras in natura, ou seja, previamente à desinfecção; desse modo $73,1 \%$ das amostras foram cloradas.

Os dados foram dispostos em gráficos que mostram a distribuição temporal dos dados analisados. A comparação concomitante das médias dos parâmetros nos poços foi executada através da análise de variância utilizando o método GT-2, com nível de significância de 5\%. De acordo com este método, os intervalos cujos limites se sobrepõem não têm médias significativamente diferentes entre si. Este método também é indicado para comparação entre amostras de tamanhos desiguais (Sokal \& Rohlf, 2012).

A análise de variância é uma extensão do teste t de Student, para a situação na qual se quer fazer comparações entre mais de dois grupos de dados. Isto é feito através da comparação de duas estimativas de variância do conjunto de dados (Von Sperling, 2005). 


\section{Resultados e Discussão}

A pesquisa evidenciou que a profundidade e a proximidade dos poços corroboram o fato de ser a mesma água do ponto de vista estatístico, por se encontrar no mesmo nível freático. Vale salientar que a qualidade das águas subterrâneas está sujeita a variações devido a influências externas em suas características, sobretudo advindo de atividades antrópicas.

Em relação ao parâmetro cor, o período global das 17 (dezessete) amostras foi de 4 (quatro) anos, de maio de 2012 a novembro de 2016. Neste período, o valor mínimo para este parâmetro foi $0 \mathrm{uH}$, e o valor máximo foi de 15 uH. Diante dos resultados obtidos apresentados na Figura 1, os poços analisados para este parâmetro se enquadraram na Portaria de consolidação ${ }^{\circ}$ 05/2017, para o seu uso pretendido.

Figura 1. Variação temporal da cor.

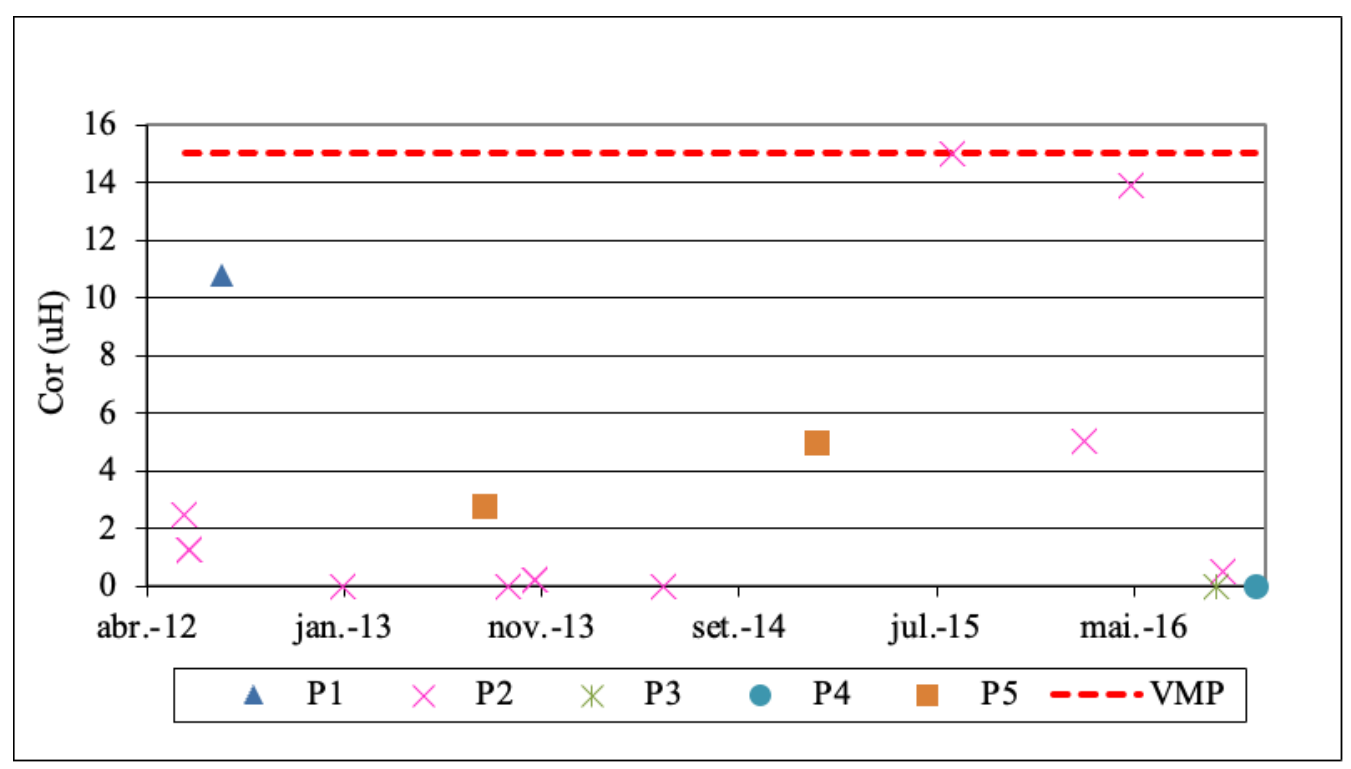

Fonte: Medeiros (2018).

A Figura 2 apresenta 26 (vinte e seis) amostras de água analisadas para a turbidez, as quais variaram de 0,1 a 5,6 UT, no período global de maio de 2012 a junho de 2018. Esse resultado mostra que a água em questão atende aos padrões de

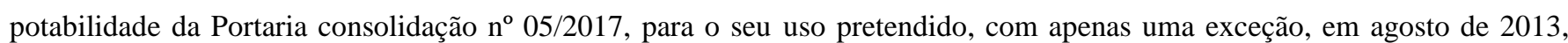
onde o poço de número 05 (P5) apresentou 5,6 UT, sendo o Valor Máximo Permitido 5 UT. 
Figura 2. Variação Temporal da Turbidez.

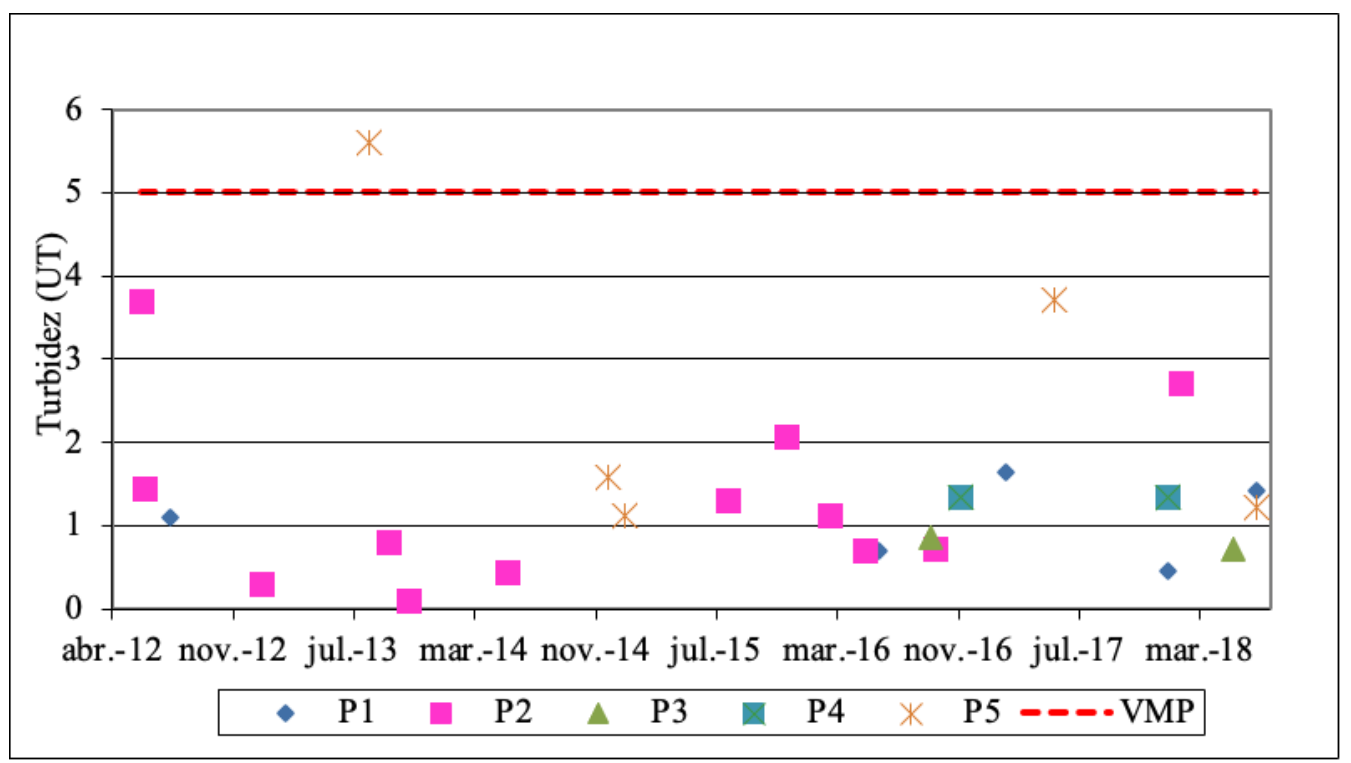

Fonte: Medeiros (2018).

Devido as informações contidas nos laudos dos poços P1, P2 e P5, foi possível fazer uma análise de variância para comparar as médias entre eles. A Figura 3 mostra a análise GT-2, a qual evidenciou que não existem diferenças significativas, ao nível de 5\%, entre as médias de turbidez dos poços P1, P2 e P5.

Do mesmo modo, os valores de turbidez encontrados no estudo de Formiga et al. (2020), em Juazeiro do Norte-CE, não apresentaram diferenças estatísticas, porém, alguns resultados ultrapassaram o VMP de 5 UT da Portaria no 05/2017.

Figura 3. Análise GT-2, comparativo das médias dos poços P1, P2 e P5.

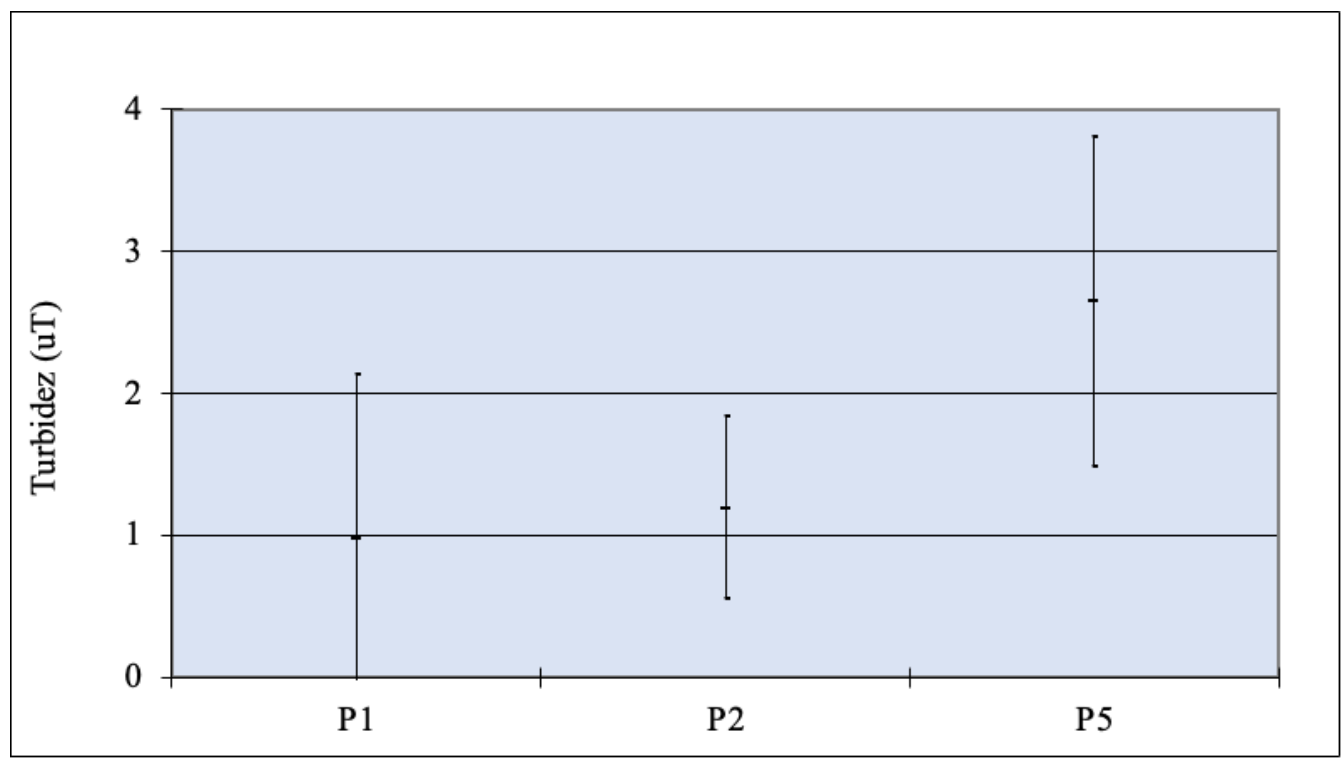

Fonte: Medeiros (2018).

A Figura 4 apresenta a variação temporal de STD dos poços P1, P2 e P3 do período de maio de 2012 a agosto de 2015. O valor mínimo foi de $0,83 \mathrm{mg} / \mathrm{L}$ no $\mathrm{P} 2$ e o valor máximo encontrado foi $178 \mathrm{mg} / \mathrm{L}$ no $\mathrm{P} 1$. 
Todas as amostras analisadas para este parâmetro se encontram dentro dos padrões de potabilidade estabelecidos pela Portaria de Consolidação $n^{\circ}$ 05/2017, assim como se enquadra na classe para consumo humano pela Resolução CONAMA ${ }^{\circ}$ $396 / 2008$.

Figura 4. Variação temporal de STD.

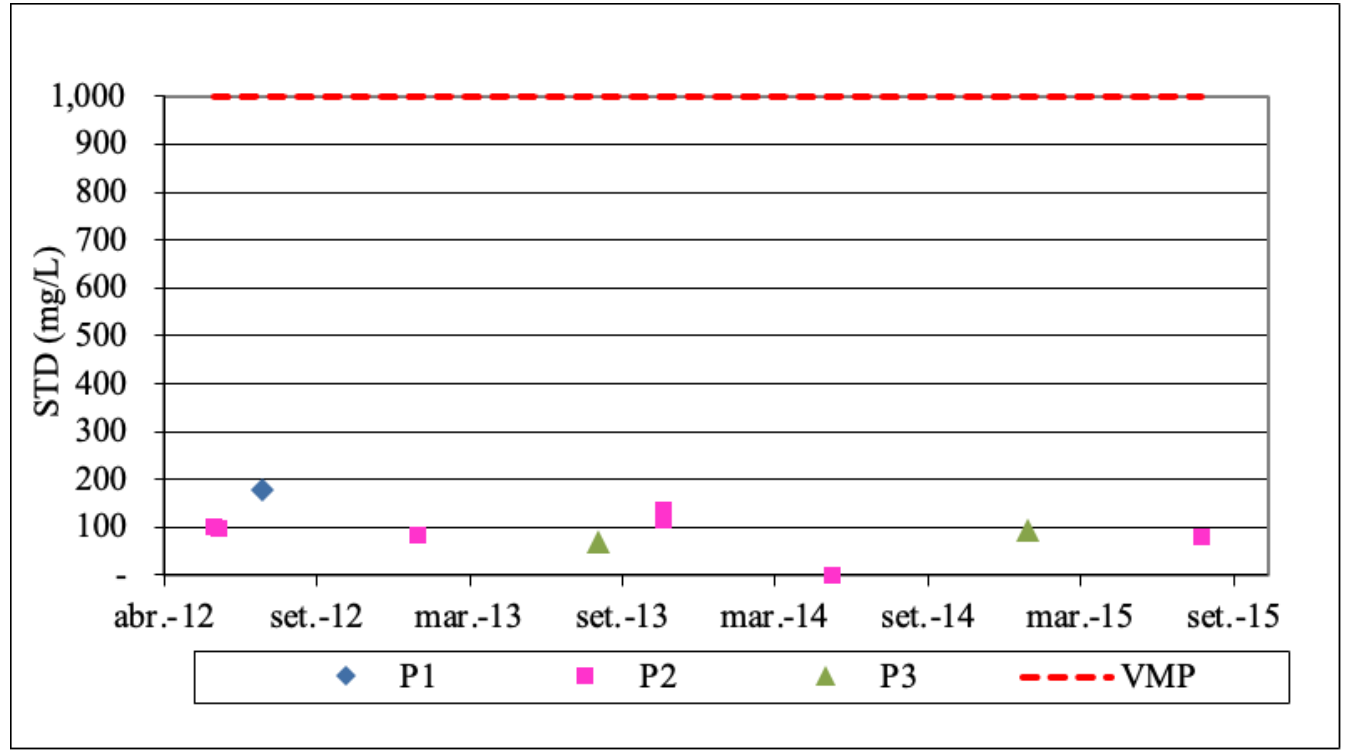

Fonte: Medeiros (2018).

A Figura 5 mostra os dados acerca de 26 (vinte e seis) amostras para o pH dos poços analisados. O período global das análises foi de maio de 2012 a junho de 2018, em que o valor máximo obtido para este parâmetro foi de 8,5 no P4 em novembro de 2016 e o valor mínimo foi de 4,3 no P2 em novembro de 2016 . Observou-se que $61 \%$ das amostras apresentaram um caráter ácido, abaixo do valor mínimo preconizado pela Portaria de Consolidação de no 05/2017 do Ministério da Saúde. Entretanto, o caráter ácido das águas avaliadas demonstrado em alguns pontos não traz risco a saúde humana, embora possua propriedade corrosiva para as tubulações do sistema de abastecimento, a longo prazo.

De acordo com a Fundação Nacional de Saúde (FUNASA), em águas de abastecimento, baixos valores de pH podem contribuir para a corrosão e agressão dessas estruturas, enquanto valores elevados aumentam a possibilidade de incrustações (FUNASA, 2014). Maia et al. (2015), ao realizarem um experimento sobre a influência do pH na corrosão do ferro, comprovaram que a taxa de corrosão em materiais ferrosos eleva-se em soluções mais ácidas, principalmente quando os valores de $\mathrm{pH}$ se tornam menores que 4.

Em um trabalho realizado na cidade de Maceió-AL, os resultados das análises realizadas no total de amostras coletadas revelaram águas em condições de acidez, com valores de pH variando de 3,92 a 5,09 (Santos et al., 2020). No estudo de Braga et al. (2018), os resultados do pH em amostras de águas subterrâneas em 12 cidades do litoral brasileiro, apresentaram $25 \%$ dos valores fora da faixa estabelecida pela Portaria nº 05/2017 do MS. Já no estudo de Pauli et al. (2014), em Toledo/PR, uma amostra apresentou valores de $\mathrm{pH}$ mais elevados $(9,0-9,9)$ quando comparado aos outros poços. Valores mais altos de $\mathrm{pH}$ no aquífero Serra Geral são comumente atribuídos a influência do Sistema Aquífero Guarani, que possui características mais básicas que o Sistema Aquífero Serra Geral (Portela Filho et al., 2005; Mocellin \& Ferreira, 2009). 
Figura 5. Variação Temporal do pH.

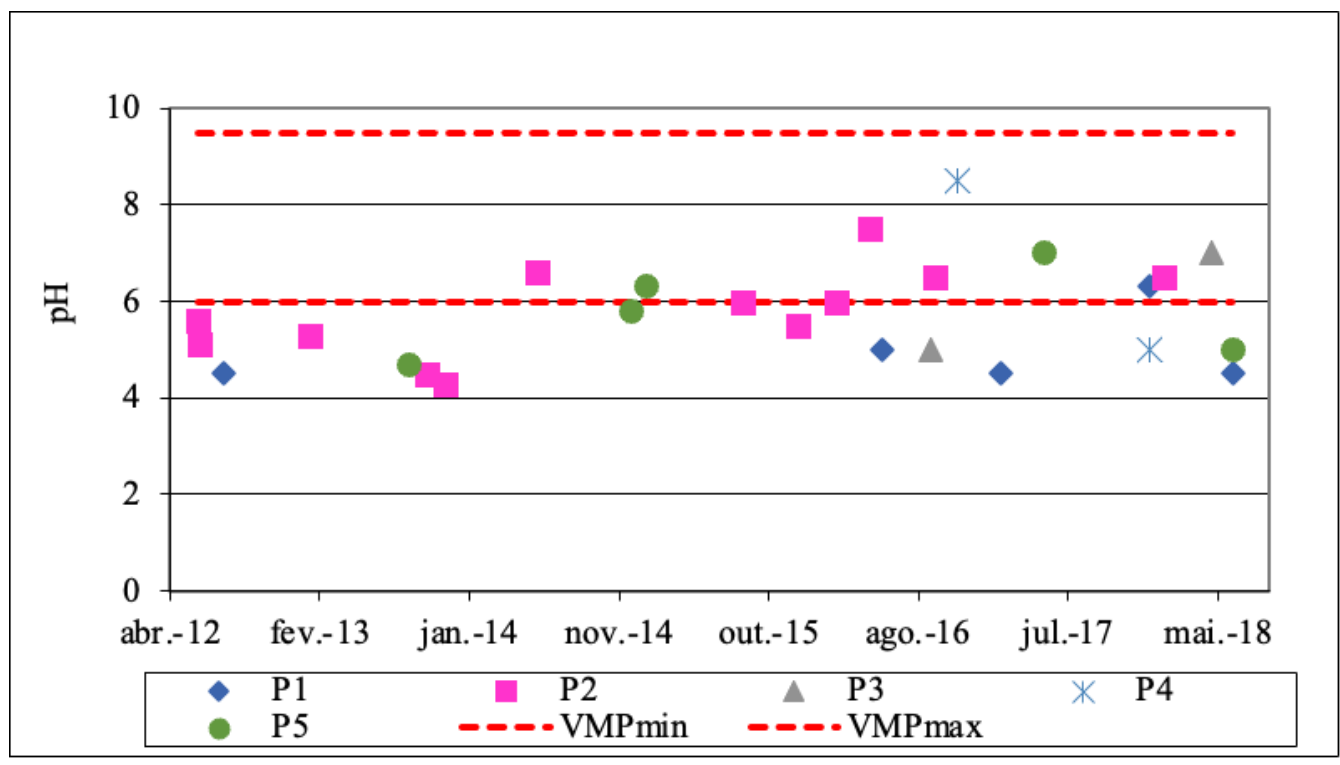

Fonte: Medeiros (2018).

A Figura 6 expõe o comparativo das médias dos poços P1, P2, P3 e P5, pela análise GT- 2 ao nível de 5\%, demonstrando que do ponto de vista estatístico, não há diferenças significativas entre as médias de pH dos poços.

Athayde Junior et al. (2009), em um estudo sobre o efeito de um antigo lixão na qualidade da água subterrânea em João Pessoa, a análise GT - 2 mostrou que houve diferença significativa entre a média do poço P6 comparada com as médias dos poços P2 e P3, sendo o poço P6 localizado no lixão, onde há liberação de ácidos, devido à decomposição do lixo, diminuindo, portanto, o valor do pH, e os poços P2 e P3 localizados na área de influência indireta do antigo lixão.

Figura 6. Análise GT-2, comparativo das médias dos poços P1, P2, P3, P4 e P5.

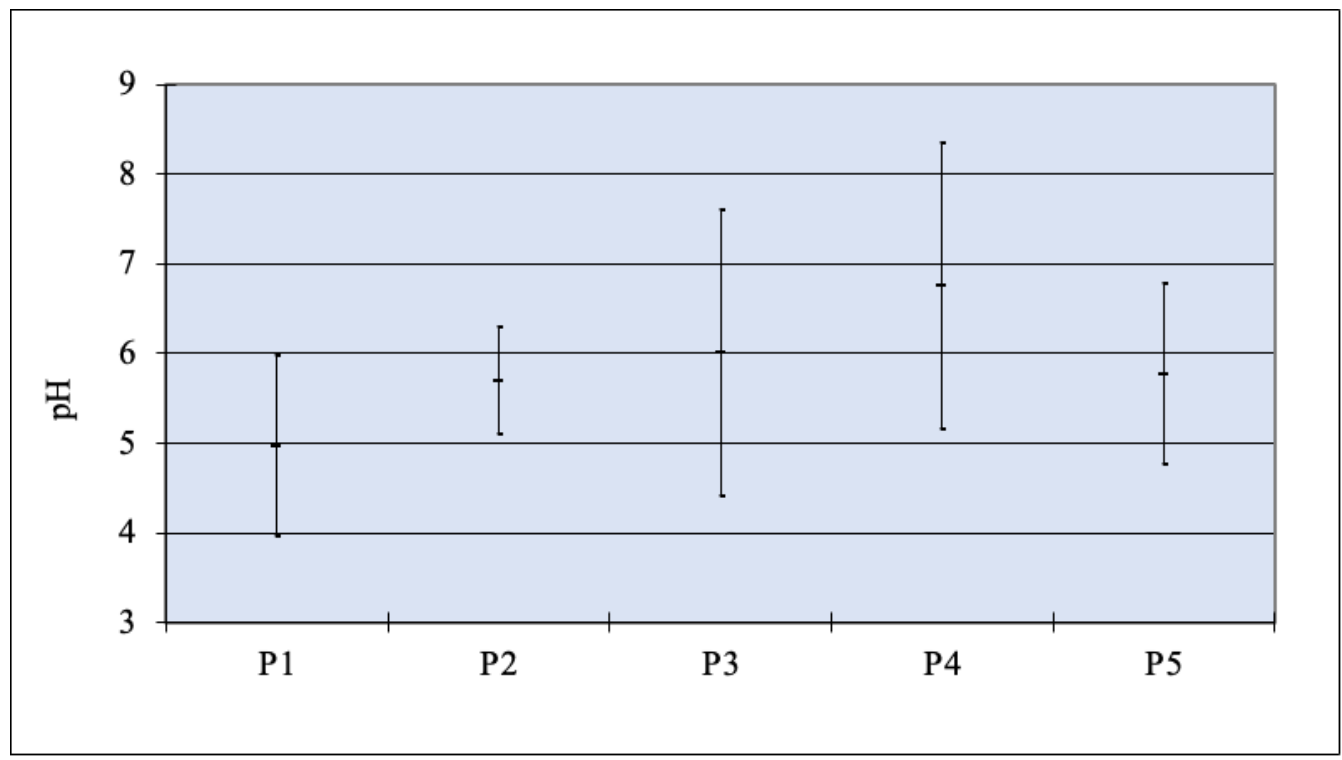

Fonte: Medeiros (2018). 
Verificou-se na variação temporal da dureza total, como mostrado na Figura 7, que o valor máximo foi de $80 \mathrm{mg} / \mathrm{L}$ no P1 em maio de 2016, e, o menor valor de $5 \mathrm{mg} / \mathrm{L}$ no P1 em junho de 2018. O parâmetro dureza total foi avaliado de maio de 2012 a junho de 2018 para 24 amostras ao longo deste período.

Além disso, 35\% das águas estudadas foram classificadas como mole e 65\% como de dureza moderada. É importante destacar que quanto maior a dureza, maior a probabilidade de ocorrer incrustação nas tubulações do sistema de abastecimento de água. De acordo com a Portaria de consolidação n 05/2017, a dureza total encontra-se dentro dos padrões de potabilidade.

Já no estudo de Braga et al. (2018), a região litorânea apresentou 75\% das amostras abaixo do valor máximo permitido (VMP). Segundo os autores, tal comportamento era esperado, pois o litoral é caracterizado principalmente pelo domínio hidrogeológico das formações sedimentares; essas formações rochosas tendem a formar aquíferos com menores índices salinos em comparação a aquíferos fissurais, ou seja, de embasamento cristalino.

Figura 7. Variação temporal da dureza total.

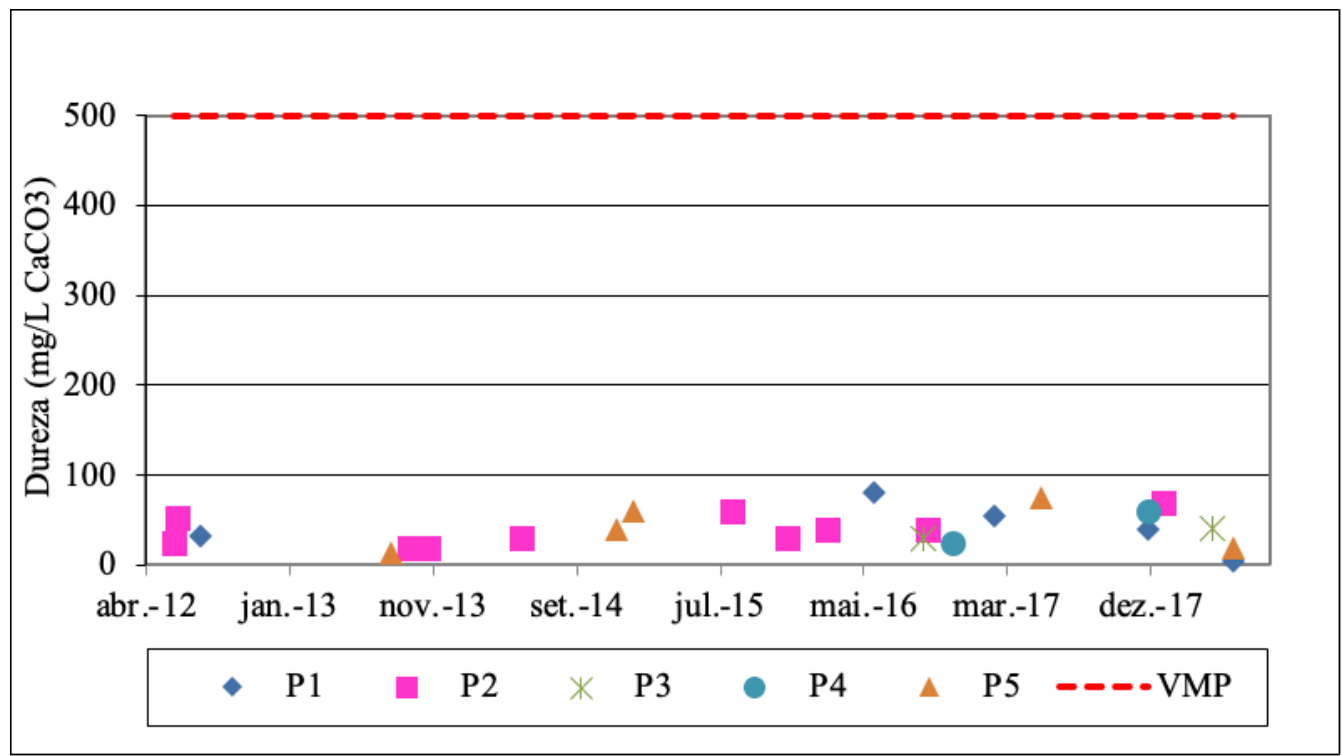

Fonte: Medeiros (2018).

A Figura 8 expõe o comparativo das médias pela análise GT-2, ao nível de 5\%, para os poços P1, P2 e P5, indicando que não há diferença significativa entre as médias de dureza total entre os poços.

Do mesmo modo que o parâmetro pH, no estudo de Athayde Junior et al. (2009), a análise GT - 2 para dureza revelou que a média do poço P6 foi significativamente diferente das dos demais poços. 
Figura 8. Análise GT-2, comparativo das médias dos poços P1, P2 e P5.

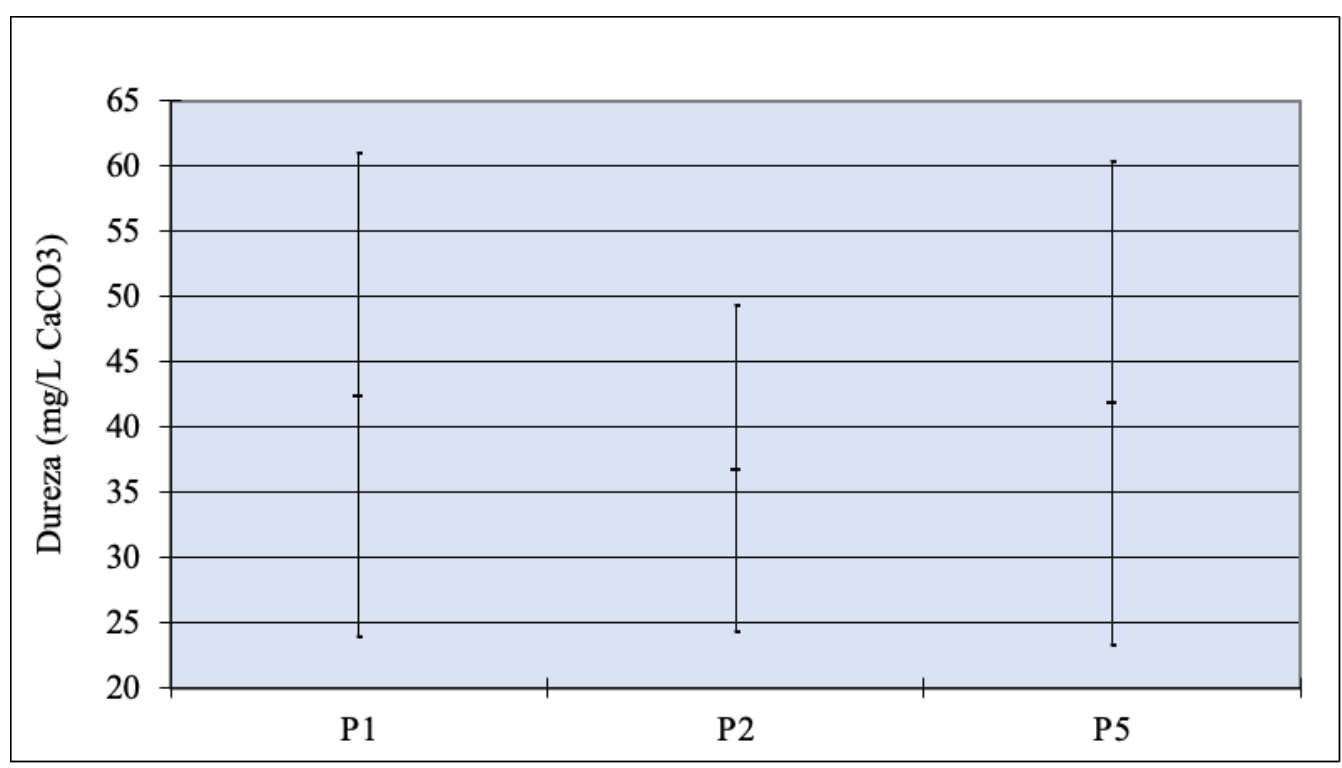

Fonte: Medeiros (2018)

Para o parâmetro cloreto, as 25 (vinte e cinco) amostras de água analisadas datam de maio de 2012 a junho de 2018 , em que o maior valor foi $50 \mathrm{mg} / \mathrm{L}$ em outubro de 2013 no P2 e em fevereiro de 2017 no P1. O menor valor para este parâmetro foi de 10 mg/L em janeiro de 2013 no P2 e, em dezembro de 2017 nos P1 e P4.

Os valores encontrados estão dentro dos padrões de potabilidade estabelecidos pela Portaria de Consolidação $\mathrm{n}^{\circ}$ 05/2017, bem como se enquadra na classe para consumo humano pela Resolução CONAMA n 396/2008.

Em Braga et al. (2018), $35 \%$ das amostras se apresentaram fora dos padrões estabelecidos pela Portaria $\mathrm{n}^{\circ} 05 / 2017$ para o parâmetro cloretos. Segundo os autores, os resultados podem ser justificados pelas atividades humanas, como por exemplo, o lançamento de efluentes, principalmente sanitários nos rios e riachos, contaminando suas águas que percolam o solo atingindo o lençol freático, justificando-se as elevadas concentrações de cloretos, já que os íons cloretos também podem ser provenientes dos efluentes sanitários. De acordo com Becker (2010), nas regiões costeiras, através da chamada intrusão da língua salina, são encontradas águas com níveis altos de cloretos. Os cloretos provocam reações fisiológicas quando ingeridos em grande quantidade. 
Research, Society and Development, v. 10, n. 6, e43510615892, 2021

(CC BY 4.0) | ISSN 2525-3409 | DOI: http://dx.doi.org/10.33448/rsd-v10i6.15892

Figura 9. Variação temporal de cloretos.

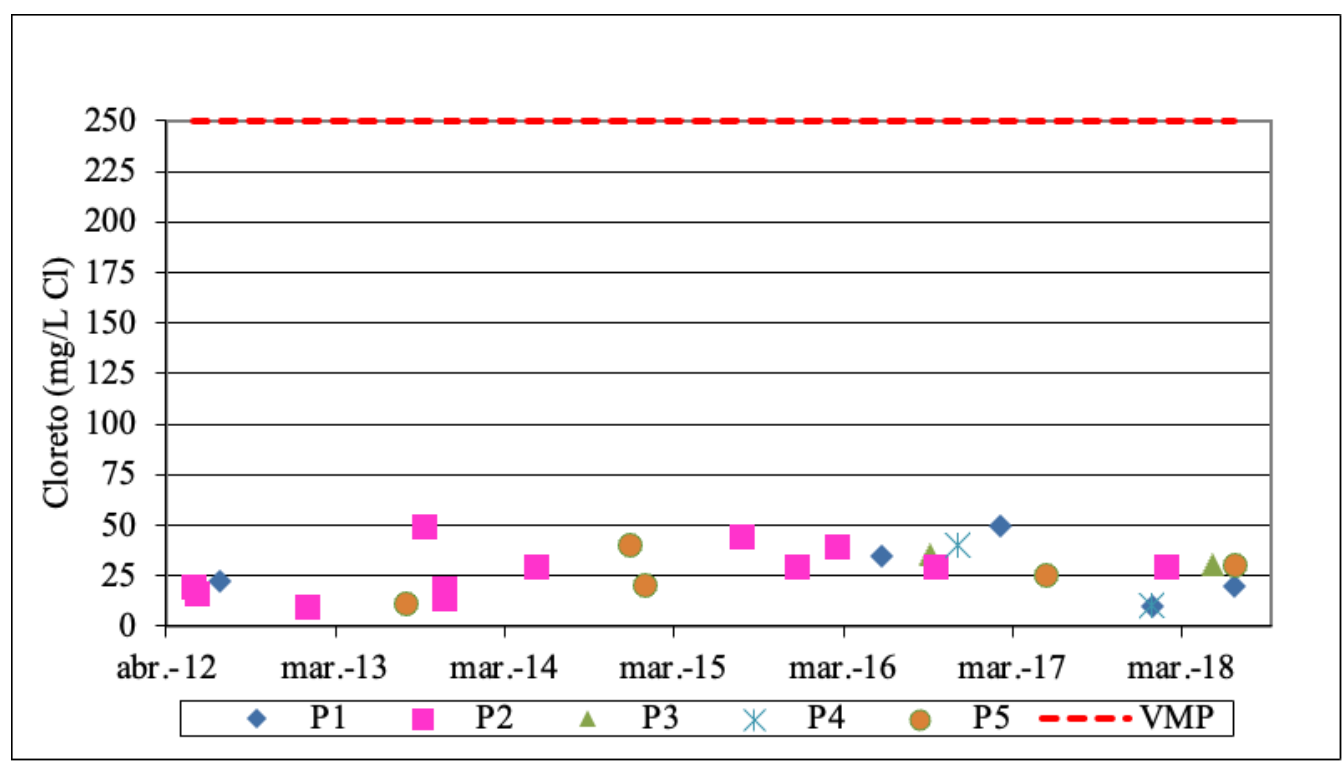

Fonte: Medeiros (2018).

Constatou-se através da análise GT-2 ao nível 5\%, que no comparativo das médias dos P1, P2 e P5 para o parâmetro cloretos não houve diferença significativa entre elas (FIGURA 10).

A análise GT - 2 realizada para o parâmetro cloreto no estudo de Athayde Junior et al. (2009), revelou que as médias dos poços localizados na área de influência direta do lixão foram significativamente diferentes dos poços localizados na área de influência indireta.

Figura 10. Análise GT-2, comparativo das médias dos poços P1, P2 e P5.

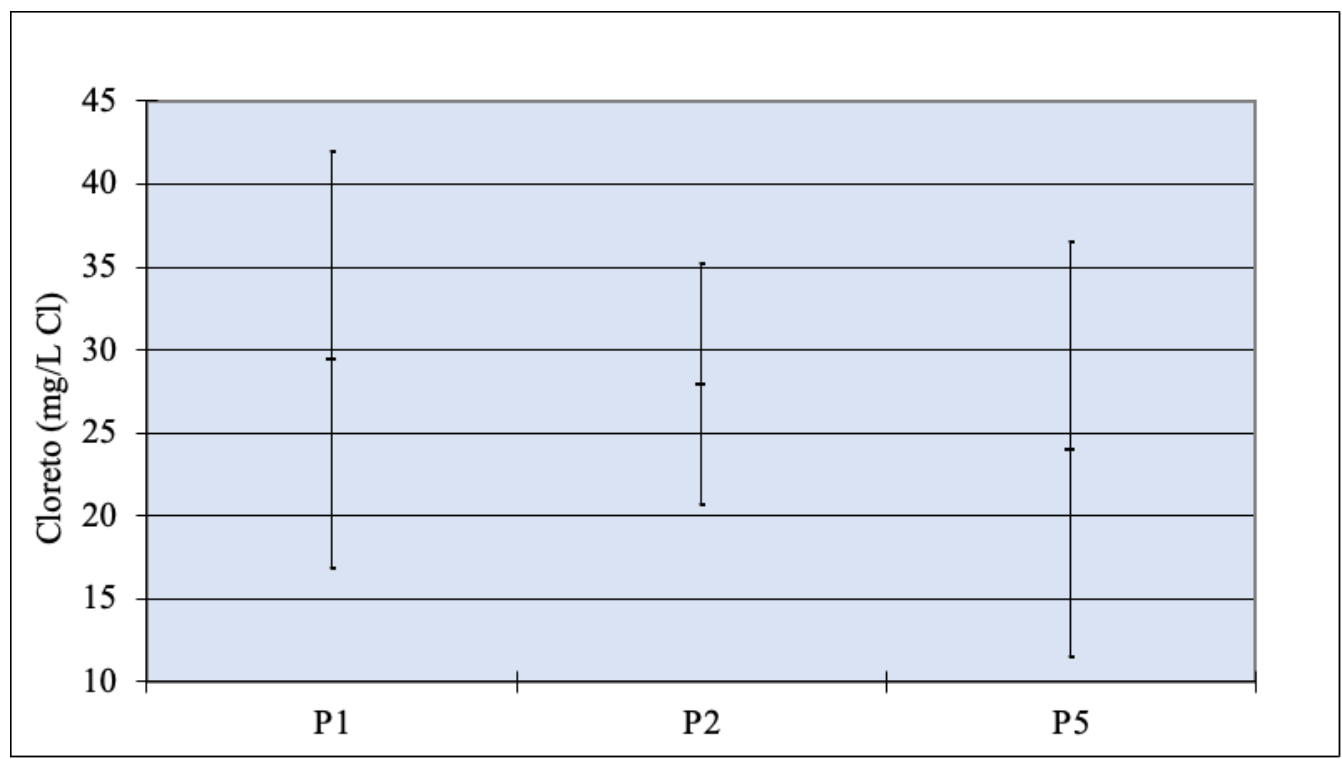

Fonte: Medeiros (2018).

A acidez variou de 0 (P5) em janeiro de 2015 a 140 mg/L (P1) em fevereiro de 2017, como ilustrado na Figura 11. A variação temporal foi de janeiro de 2013 a junho de 2018 em suas 17 amostras. Este parâmetro não está disposto na legislação vigente, logo não possui valores de referência. 
Figura 11. Variação temporal da acidez.

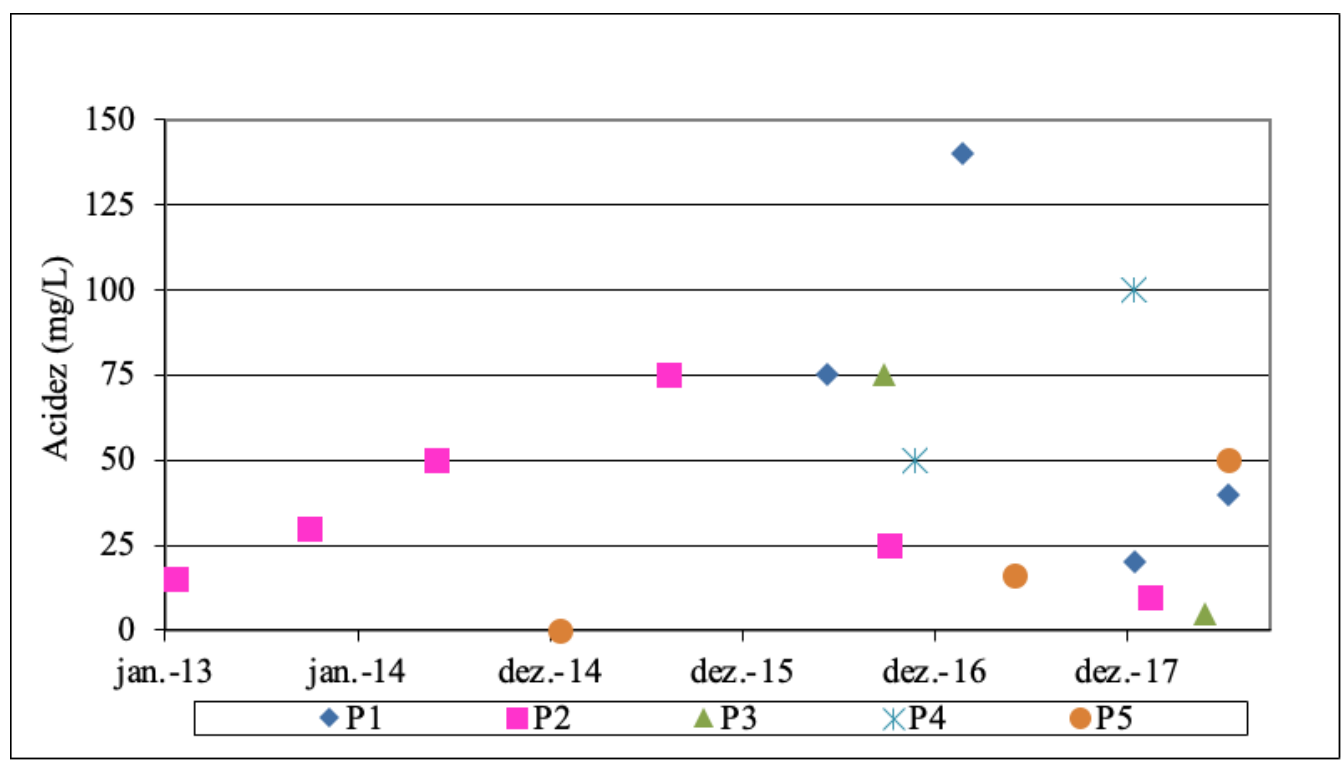

Fonte: Medeiros (2018).

Variação menor foi observada no trabalho de Martiori e Silva (2015), no qual foram encontrados valores de acidez que variaram de 21,9 a 41,5 mg/L em águas subterrâneas do município de Caxambu do Sul-SC.

Através da análise GT-2 ao nível de 5\% para o comparativo das médias para a acidez (FIGURA 12) para os poços P1, P2 e P5, indica que não ocorre significativamente médias diferentes entre eles.

Figura 12. Análise GT-2, comparativo das médias dos poços P1, P2 e P5.

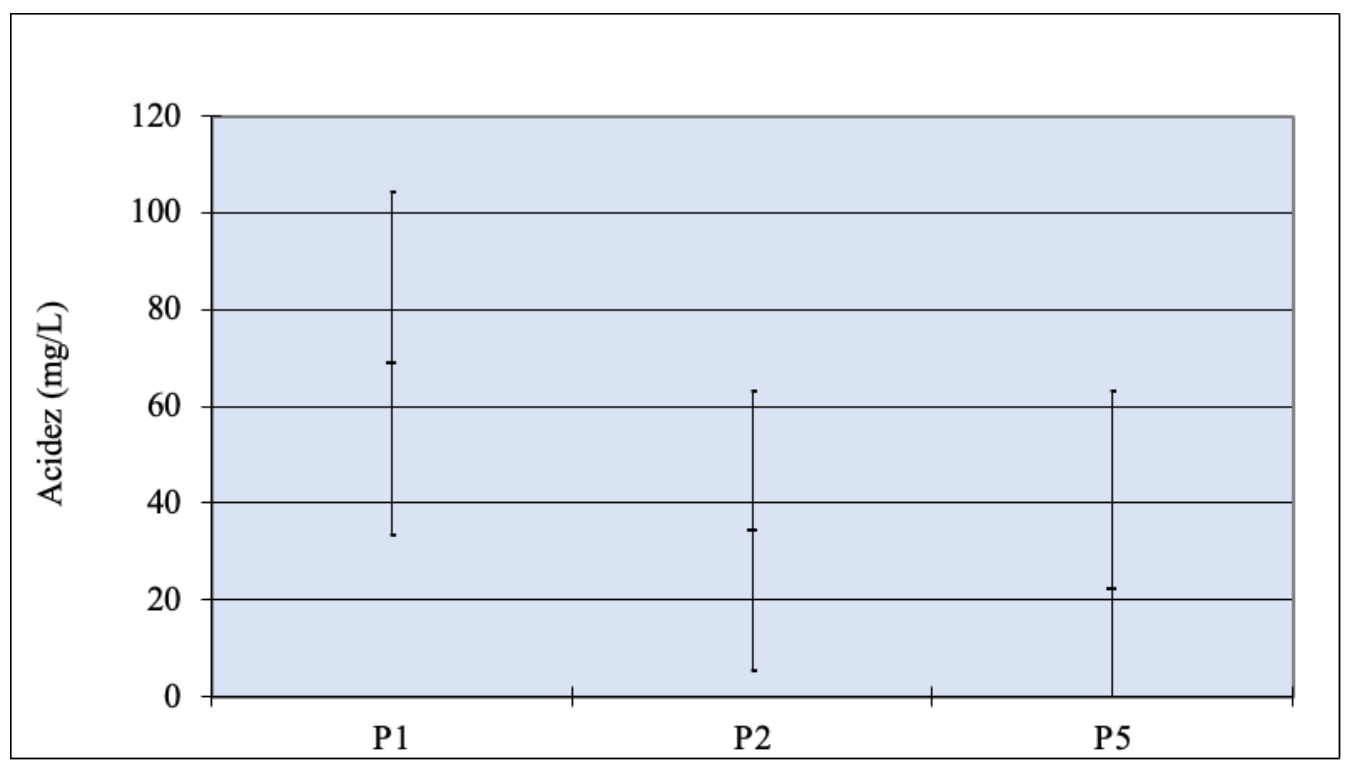

Fonte: Medeiros (2018).

Em relação aos parâmetros bacteriológicos coliformes totais e Escherichia coli, os 26 (vinte e seis) laudos resultaram em ausência em $100 \mathrm{~mL}$ da amostra em 84,6\% das análises. A presença de coliformes totais e Escherichia coli ocorrem apenas em algumas das análises realizadas previamente a desinfecção da água, no P1 em fevereiro de 2017, no P4 em novembro de 2016, e no P5 em dezembro de 2014 e maio de 2017. 
Esse percentual de contaminação na zona urbana pode ser devido a vários fatores, sobretudo poços que geralmente apresentam localização inadequada (por exemplo, próximos às fossas sépticas), falta de manutenção e cuidado antes de utilizar a água para consumo humano (Colvara; Lima \& Silva, 2009).

Vale ressaltar que nenhuma das análises após o tratamento (desinfecção), ou seja, a água que de fato é distribuída para a população apresentaram coliforme total e Escherichia coli em $100 \mathrm{~mL}$ de amostra.

Segundo a Portaria de Consolidação nº 05/2017 e a Resolução CONAMA n 396/2008, as águas para consumo humano devem apresentar nos resultados da amostra para análise, uma ausência em $100 \mathrm{~mL}$ de coliformes totais e Escherichia coli.

\section{Considerações Finais}

A apuração dos resultados demonstrou não haver variações espaciais (entre os poços) nem temporal (ao longo do período global estudado) nos parâmetros avaliados, ocorrendo apenas alguns picos na cor e na turbidez, conforme podem ser visualizados por meio da inspeção gráfica.

Para a maioria dos parâmetros estudados, houve atendimento aos padrões de potabilidade estabelecidos pela Portaria de Consolidação $n^{\circ}$ 05/2017. Exceção a isto, foram vários episódios de pH abaixo de 6, que é o limite mínimo preconizado pela Portaria supracitada. Cabe destacar que os valores de $\mathrm{pH}$ precisam ser corrigidos antes do consumo da água pela população. Com relação a Resolução CONAMA n 396/2008, os parâmetros dispostos na Resolução e avaliados neste estudo (Sólidos Totais Dissolvidos, Cloretos, E. Coli e Coliforme Total) atenderam os requisitos para o enquadramento na classe de uso para consumo humano.

A desinfecção se mostra um tratamento eficiente para as águas subterrâneas da região, visto que nenhuma das amostras de água coletadas após o tratamento, mostrou presença de coliforme total e Escherichia coli.

Dada a importância da qualidade das águas subterrâneas, faz-se necessário um monitoramento periódico e contínuo a fim de identificar possíveis alterações nos parâmetros e investigar prováveis fontes de contaminação, as quais podem refletir em problemas no que diz respeito à saúde pública. Dessa maneira, como sugestão de pesquisas futuras, pode-se citar a ampliação espaço-temporal da amostragem, com a aplicação de modelos matemáticos para avaliação da tendência de variação temporal da qualidade da água subterrânea na região.

\section{Referências}

Agência Nacional de Águas. (2017). Conjuntura dos recursos hídricos no Brasil 2017: relatório pleno. Brasília, DF: ANA.

Apha, Awwa, Wef. (2012). Standard Methods for Examination of Water and Wastewater. 22nd Edition, American Public Health Association, Washington DC.

Associação Brasileira de Águas Subterrâneas. (2018). Águas Subterrâneas. Brasil. http://www.abas.org/educacao.php

Athayde Junior, G. B., Nóbrega, C. C., Gadelha, C, L. M., Souza, I. M. F. \& Fagundes, G. S. (2009). Efeito do antigo Lixão do Roger, João Pessoa, Brasil, na qualidade da água subterrânea local. Ambi-água, 4(1), 142-155.

Becker, H. (2010). Controle analítico de águas. Versão 4. Universidade Federal do Ceará. Fortaleza. 84 p.

Braga, E. S., Freitas, C. B. F. B., Mendes, L. S. A. S., \& Aquino, M. D. (2018). Avaliação da qualidade de águas subterrâneas localizadas no litoral, serra e sertão do Estado do Ceará destinadas ao consumo humano. Águas Subterrâneas, 32(1), 17-24.

Brasil. (1997). Lei $n^{o} .9 .433$ de 08 de janeiro de 1997. Da Política Nacional De Recursos Hídricos. Brasília - DF. http://www.planalto.gov.br/ccivil_03/LEIS/L9433.htm

Brasil. (2017). Portaria de Consolidação $n^{\circ} 05$ do Ministério da Saúde de 28 de setembro de 2017. consolidação das normas sobre as ações e os serviços de saúde do Sistema Único de Saúde. Brasília - DF.

Brasil. (2001). Resolução CNRH $n^{o} 15$ de 11 de janeiro de 2001. Estabelece diretrizes gerais para a gestão de águas subterrâneas. Brasília - DF http://www.aesa.pb.gov.br/aesa-website/wp-content/uploads/2018/02/Resolu\%C3\%A7\%C3\%A3o-n\%C2\%BA-15-de-11-de-Janeiro-de-2001-CNRH.pdf 
Research, Society and Development, v. 10, n. 6, e43510615892, 2021

(CC BY 4.0) | ISSN 2525-3409 | DOI: http://dx.doi.org/10.33448/rsd-v10i6.15892

Brasil. (2008). Resolução CONAMA $n^{\circ} 396$ de 03 de abril de 2008. Dispõe sobre a classificação e diretrizes ambientais para o enquadramento das águas subterrâneas. Brasília - DF. http://pnqa.ana.gov.br/Publicacao/RESOLU\%C3\%87\%C3\%83O\%20CONAMA\%20n\%C2\%BA\%20396.pdf

Colvara, J. G., Lima, A. S., \& Silva, W. P. (2009). Avaliação da contaminação de água subterrânea em poços artesianos no sul do Rio Grande do Sul. Brazilian Journal of Food Technology, Campinas, II SSA.

Formiga, A. C. S., Figueiredo, C. F. V., Oliveira, F. F. D., Sousa, G. M., Oliveira, S. R., Santana, F. C. C., Oliveira, P. A. T. \& Medeiros, R. L. B. (2020). Variação espaço/temporal da qualidade da água subterrânea do Município Juazeiro do Norte - Ceará. Research, Society and Development, 9(9), 1-22.

Fundação Nacional de Saúde. (2014). Manual de controle da qualidade da água para técnicos que trabalham em ETAS. Brasília, DF: Funasa.

Instituto Brasileiro de Geografia e Estatística. (2010). Censo Demográfico 2010.

Lima, E. A., Nascimento, D. A., Dourado, T. D. C., \& Brandão, L. C. R. (2004). Mapeamento hidrogeológico da folha Sb.25-Y-C João Pessoa-Paraíba. XIII Congresso Brasileiro de Águas Subterrâneas. Cuiabá - MT.

Maia, D. J., Segre, N., Scatigno, A. C., \& Stella, M. B. (2015). Experimento sobre a influência do pH na corrosão do ferro. Química Nova na Escola: Experimentação no Ensino de Química, 37(1), 71-75.

Martiori, K., Silva, M. L. N. (2015). Análise da qualidade da água de poços rasos no interior do município de Caxambu do Sul - SC, um estudo de caso. Trabalho de Conclusão de Curso (Bacharel em Engenharia Ambiental). Universidade Federal da Fronteira do Sul, Chapecó-SC.

Medeiros, L. T. G. (2018). Avaliação da qualidade da água subterrânea na região dos bancários em João Pessoa - PB. Trabalho de Conclusão de Curso (Bacharel em Engenharia Ambiental). Universidade Federal da Paraíba, João Pessoa-PB.

Meneses, L. F., Silva, T. C., Figueiredo, E. C. T. P.; \& Rafael, R. A. (2011). Evolução urbana e vulnerabilidade dos aquíferos superiores no município de João Pessoa - PB. Revista Brasileira de Cartografia, 63(2).

Mocellin, R. C., \& Ferreira, F. J. F. (2009). Conectividade e compartimentação dos sistemas aquíferos Serra Geral e Guarani no sudoeste do estado do Paraná, Brasil, Revista Brasileira de Geociências, 39(3), 567-579.

Pauli, A. R., Quiñones, F. R. S., Palácio, S. M., Marin, P., Oliveira, S. P. D., \& Colombo, A. (2014). Avaliação da qualidade da água subterrânea utilizada para consumo humano na região rural do munícipio de Toledo-PR. XVIII Congresso Brasileiro de Águas Subterrâneas, Belo Horizonte - MG.

Portela Filho, V. C., Ferreira, F. J. F., Rosa Filho, E. F., \& Rostirolla, S. P. (2005). Compartimentação magnética-estrutural do Sistema Aquífero Serra Geral e sua conectividade com o Sistema Aquífero Guarani na região central do Arco de Ponta Grossa (Bacia do Paraná), Revista Brasileira de Geociências, 35(3), 369-381.

Santos, J. S., Nascimento, V. X., Costa, J. G., Toledo, P. H. O., Rocha, T. J. M., \& Miranda, P. R. B. (2020). Avaliação da qualidade da água subterrânea em poços urbanos considerando os efeitos da sua evolução temporal em parte da cidade de Maceió-AL. Revista Princípia, 53, 54-67.

Sokal, R. R., \& Rohlf, F. J. (2012). Biometry: the principles and practice of statistics in biological research. 4ª Ed. - New York: W.H. Freeman.

Von Sperling, M. (2005). Introdução à quantidade das águas e ao tratamento de esgotos. $2^{\mathrm{a}}$ edição. Belo Horizonte. Departamento de Engenharia Sanitária e Ambiental.

World Water Assessment Programme. (2015). The United Nations World Water Development Report 2015: Water for a Sustainable World. Paris, UNESCO. 